\title{
Community water management. Is it still possible? Anthropological perspectives
}

\section{Toufik Ftaïta}

\section{(2) OpenEdition \\ 1 Journals}

Electronic version

URL: http://journals.openedition.org/aa/1161

DOI: 10.4000/aa. 1161

ISSN: 2357-738X

\section{Publisher}

Programa de Pós-Graduação em Antropologia Social (UnB)

\section{Printed version}

Date of publication: 1 December 2011

Number of pages: 195-212

ISSN: 0102-4302

\section{Electronic reference}

Toufik Ftaïta, "Community water management. Is it still possible? Anthropological perspectives",

Anuário Antropológico [Online], v.36 n. 1 | 2011, Online since 24 November 2015, connection on 28 April 2021. URL: http://journals.openedition.org/aa/1161 ; DOI: https://doi.org/10.4000/aa.1161

\section{(c) (i) (9)}

Anuário Antropológico is licensed under a Creative Commons Atribuição-Uso Não-Comercial-Proibição de realização de Obras Derivadas 4.0 International. 


\title{
Community water management. Is it still possible? Anthropological perspectives
}

\author{
Toufik Ftaïta \\ University Nice Sophia Antipolis
}

\section{Water as an eminently anthropological issue}

The topic of water has several dimensions: ecological, economic, technical, social, political, and religious. The ecological dimension has received greater attention due to the geographical and climatic conditions that affect water availability or scarcity, which in turn contribute to its uneven distribution between countries and even within the same country.

However, the economic dimension is increasingly critical as water changes from being a popular representation as a heavenly free gift (religion and rituals about water are quite important) to the object of property by the state or by the powerful. As such, water becomes an issue of political power and economic capital that excludes the poorest sectors of society. A critical aspect of this inequality is that over one billion people worldwide have no access to drinking water. The Millenium Development Goals aiming at improving the poor's access to clean water and sanitation are at a standstill due to bureaucratic delays and profiteering maneuvers that structure investment projects and donations.

Despite protests from some NGOs at global World Water Forums, access to drinking water as a fundamental human right is far from being secured. Water is now perceived as a commodity. Production and distribution of drinking water is a highly profitable business to specialized companies, as there is no competition, unlike other economic activities (very few specialized companies in the world share the profits, France being an exception with two strong companies). However, there are some mobilization efforts against water privatisation and commodification. The Cochabamba events and the struggles of poor farmers remind us that water is not reduced to pipes and concrete, but a social and political issue of the utmost importance. Conflicts over use and ownership of this resource are not new. The social and political history of several communities is a constant reminder that water is not only a source of life, but also of conflict and death. Studies that include oasis communities in North Africa show that water was and continues to be constitutive of oasis societies. Their models for water 
appropriation and distribution bring to the fore their political and religious structures. In these arid areas, where water is an object of desire, its massive and extensive ownership by some oasis families has helped establish their political and religious authority (Pascon, 1984a; Bédoucha, 1987; Ftaïta, 2006a,b).

Water scarcity and waste have prompted the need for new management technologies and institutional reforms. In the South, irrigation in agriculture is now widely used and has become the largest consumer of water (between $70 \%$ and $80 \%$ ). There is, however, a growing competition between industry, tourism and drinking water production. The latter threatens some areas where water resources formerly used for irrigation are transferred to meet the drinking water needs of urban and rural populations. In turn, tourism has brought about serious problems for farmers, especially, where water resources are limited. Several examples illustrate the overconsumption of water in tourism development and its impact on the sustainability of local farming activities. Two such examples are the Tozeur oasis in Tunisia and the city and surrounding region of Marrakech in Morocco.

The new challenges posed by the current concern with climatic change and greater water scarcity have become a major concern for the rational management of water. But what does the notion of «sound water management» really mean? Is it a kind of publicity for new technologies, including new irrigation techniques, allegedly more effective in saving water than traditional techniques? The anthropological literature has shown that the notion of rationality is not exclusive to modern water management models. Moreover, abundance or scarcity of water does not affect the willingness of local communities to efficiently manage their water resources (Geertz, 1972; Ftaïta, 2006a). Likewise, when we talk about rational management of water, we often forget to focus on the hierarchical structure of water ownership and distribution (Bédoucha, 1987; Ftaïta, 2006b).

Moreover, what does the idea of "good governance" of water imply? Could it be the need to supersede old community-based models of water management (largely structured by local customary law), regarded as unsuitable for modernity, by imposing a new national legal framework to regulate water ownership and access warrantied by the state? What happens to the communities faced with these institutional changes? How do local actors behave viz-à-viz state interventionism? What strategies and logic do they deploy to enter or evade the system? These are questions that show how the water issue surpasses the narrow technological or ecological framework that constrains it. The present situation calls for an anthropological analysis, now that local communities experience 
significant changes and conflicts increase over the use and ownership of water, undermining the sustainability of oasis systems, and hence, their very existence.

I shall focus on the recent establishment of WUAs (Water Users Agricultural Associations) in Morocco as an institutional innovation to participatory irrigation management. The country's social and political history shows that for centuries irrigation management was carried out by the communities in collective projects for water appropriation. A detailed analysis of community management models of water irrigation reveals their diversity and the importance of customary rights in local production and reproduction of oasis systems. I follow the lines proposed in the anthropology of Water and Irrigation. Frequently studies of irrigation communities focus on the technical and legal aspects of irrigation, neglecting the social and political issues involved in the ownership of and access to water. The introduction of new management models of irrigation reveals the serious challenges entailed in the establishment of an imposed and enduring model for water management that disregarded local realities and knowledge, as well as traditional irrigation skills. It may be easy to set up a model for managing irrigation in a newly developped area, but it is difficult to replace older models of community water management. The difficulties lie in the fact that these local models have been socially, historically, technically and politically shaped by local agents. Moreover, it is the diversity of these models - providing a variety of rules and both formal and informal practices for the communities - that is responsible for the functioning of oasis systems. In fact, any new model of water management involves the renegotiation/social reconstruction and redefinition of the local power structure (Hunt, 1989; Ostrom, 1992; Ftaïta, 2006a,b).

\section{The foundations of community management of oasis irrigation water: the salience of customary rights}

In the history of Moroccan irrigation, we can distinguish three periods of water ownership and management. The first covers the pre-colonial period during which water ownership and management were structured around Islamic law (shariaa) and local custom (orf). As in many Muslim countries, the principles of water management in Morocco intertwined these two legal codes (shariaa and orf), thus offering different practices and rules from one region to another and even within a single geographical area. This overlap of rights reveals Islam's ability to conduct former practices without questioning religious orthodoxy (Sonnier, 1933; Roché, 1956; Bouderbala, 1984; Ftaïta, 2006a). It is clear that the notion of ijmaa (consensus doctorum) leaves much room for local custom, provided it is not inconsistent with Shariaa guidelines. This situation continued 
until the French protectorate, which marked out a new phase in the process of ownership and management of irrigation water. With the arrival of the French, a new hydraulic reform deeply modified the previous one, by introducing the concept of public domain. However, the principles of public ownership of water resources were soon to clash with those of the local communities. Indeed, to recognize state ownership of water was to incur in the expropriation from oasis communities of their customary and inherited water rights. Faced with protests, the new Water Code has finally recognized customary water rights.

The third phase covers the independence period. Morocco has maintained the state model of water management inherited from the French. Farm programs have privileged large-scale irrigation systems characterized by the construction of big dams and the modernization of irrigation techniques. In 1967, a major reform created the Regional Offices for Agricultural Development (ORMVA) and decentralized administrative structures in charge of irrigation. Unlike followers of the oasis models, farmers were regarded as mere users of water and had to pay a fee to use it. This situation lasted until 1992 when a new law established associations of agricultural water users (WUAs). ${ }^{1}$ The purpose of this legislation is to encourage water users to form associations to support the management of irrigation networks and thus contribute to the costs of rehabilitation and maintenance. It is a participatory approach to irrigation. This new model of water management and irrigation systems has been beneficial to farmers who up until then had to face the hurdles of bureaucracy and the authority of the Regional Offices for Agricultural Development. Participation in WUAs could have resulted in a new institutional framework that allowed farmers to act and be recognized by the state, but, as we shall see, this is not the case. Moreover, legally speaking, this associative model cannot be limited to areas managed by ORMVA. It must cover all irrigated areas, including those where irrigation water is collectively managed, namely, the oases.

The associative model of water users clearly unveils the bankruptcy of the state model for the management of water resources. In the case of Morocco, as elsewhere in the world, the associative model results from structural adjustments imposed by funding agencies (Herzenni, 2002). The deficit in management on the part of regional offices for agricultural development and their inability to cover the fees required for financial balance and investment returns has forced the state to gradually withdraw and charge water users for the cost of maintenance and rehabilitation networks, appealing to the principles of participatory irrigation management. However, the principle of user participation is not new in Morocco. Traditionally, local communities that collectively acquired 
hydraulic works are obliged to share the repair and maintenance costs. The oasis example is a significant model of community-based management of irrigation water. How novel, then, is this new institutional model? To understand the differences between the associative model and the various community-based models, we need a thorough analysis of both institutional forms.

The community management model is characterized by individual ownership of water rights and collective ownership of water works. Owning water rights involves certain rights and duties. One becomes a water owner by participating in the installation of water works. Owners are then responsible for repairs and maintenance when necessary. Needless to say, individual appropriation is only meaningful in the context of collective ownership of the hydraulic works: if the community recognizes the individual right of water owners, these cannot dodge their collective duties as inscribed in customary law. As common law varies from one community to another, only a coomunity's social and political history can shed light on the conditions that led to its development. This is a social construct that can be amended or modified according to the community's situation. Not all oasis-based farmers own water rights. The status of water owner is transmitted either by inheritance or by capitalization. A share of water may be directly bought from another water owner, provided the transaction complies with the requirements of local customary law (prohibition to sell water to a stranger) or when the rehabilitation of water points requires large sums of money the community cannot afford. In this case, the community sells one or more days of water by extending the water cycle to as many days as necessary (the sale of two days of water in a cycle of seven days will result in the extension of the water cycle; for instance, in a two-day extension of a new water cycle, there will be nine days instead of the previous seven).

Community water management involves both the technical handling of the irrigation network and the social control of water distribution and allocation among the rights holders. We cannot understand the management of water in the oasis without considering the social and political dimensions of water ownership and distribution. Technical management of water involves setting up the entire infrastructure, all the way from the hydraulic plant to the distribution channels to the plots. ${ }^{2}$ We can only understand this system in the context of the social management of irrigation water because of the diversity of practices and models offered by oasis-based farmers. It is not unusual to observe different practices and ways of appropriation and distribution of water in the same geographically and culturally homogeneous area. These practices are formalized by legal rules deriving from common law. For this reason, the rich oasis hydraulic 
heritage must be preserved. Therefore, the technical, agronomical and legal knowledge and expertise offered by the material and immaterial heritage is anything but outdated. It reveals the intimate connection between oasis societies and their environment and the delicate balance between the resources available and access to them. Local customary rights pay close attention to the conditions of access to natural resources. There are penalties to punish abuses. Control is exercised by the djemaa, a traditional assembly with social and political power in North African oasis communities. The major advantage of these legal practices is the space they give local communities for social and political negotiation. Rules over water ownership, access and sharing may be strict, but they make room for negotiation without which any cooperation would be impossible. This is perhaps the reason why Clifford Geertz's (1972) attempt to compare the Balinese and Moroccan models failed. Whereas water distribution in Bali is tightly controlled, in Morocco, it allows water owners to engage in considerable negotiations and arrangements. Social negotiation is necessary for the survival of the system, given oasis climatic conditions and water scarcity. It also allows farmers without water rights to benefit either from renting or from Rahn. ${ }^{3}$ For example, small holders of water rights are often forced to transfer their share of water to the water guards in charge of allocation when they cannot take it that day, because the right amount of water might be lost in the canals before reaching their plot. On these occasions, water guards must redistribute that water. The situation becomes more complex when a farmer owns parts of water from several sources with different irrigation cycles. Some farmers negotiate intensely to have all their shares on the same day and thus be able to irrigate large tracts or plots that are far apart (Ftaïta, 2006). These negotiations are maintained by the water owners while clearly observing the local customary rules that define the terms of water distribution among the owners. Sustainability of the oasis system cannot be maintained without this joggling with rules. The djemaa assembly, socially and politically legitimized by social contract, complies with these negotiations and does not consider them to be an impediment to oasis life. The djemaa guarantees the social cohesion that is essential for the production and reproduction of oasis society.

The legal content of customary law allows the djemaa to ensure the smooth running of the oasis. Order enforcement and conflict resolution among water owners have been major concerns in the oases. To ensure the safety of property and persons, representatives of the djemaa appointed auxiliary staff or assistants, ineflass. The legal system could not be efficient without the garden police (ineflass), responsible for suppressing any exaction; only official djemaa 
members could dispense the designated staff.

Distribution of water among beneficiaries is often entrusted to water guards ${ }^{4}$ (locally called abbar, turjjmani, amazal, or amghar). They must meet specific criteria, such as seniority as water owners, or sensitivity to negotiate and mediate, honesty and fairness. The position of water guard is transmitted from father to son, but the community can remove him from office at any time. Rare cases of water theft or fatal quarrels have occurred at water distribution points (majless) and severely punished by customary law. Water guards receive compensation directly from the owner. In the past, farmers offered them a part of their harvest, but nowadays, they are paid either in water taken directly from the share distributed, or in cash corresponding to the share of water distributed. Monetarization of social relations has changed the water distribution system. For example, in the oasis of Talaint (SW Morocco), the water distribution unit is the clepsydra/water clock (tassa or tighira), a 12-minute water unit (Ftaïta, 2010a). Currently, the water owner receives only 11 minutes of water, the twelveth minute being used to pay the water guard. In this oasis, a 12-hour day (ferdia) contains 60 tassa, hence, the water guard actually gets five tassa of 12 minutes each, that is, one hour of water per ferdia distributed. ${ }^{5}$ In addition, there are the shares from small holders who are unable to use water on a given day and thus leave it to the water guard who, in turn, leases it to other farmers. This practice, called tafwit (temporary concession of water portions) confers the water guards considerable power. In some oases, the release of large amounts of water bring about huge sums to water guards, thus increasing their power over small owners. We can better appreciate this point if we consider that small water owners make up the majority of owners, while only a few notable and rich families hold almost all of the water. The power of water guards is even greater for those who are obliged to rent water. In these circumstances, it is understandable that some oases do not trust water guards.

Besides these aspects related to power issues, the social management of water also reveals the ability of irrigators to deal with social, political and even ecological constraints. For example, droughts and water scarcity are managed by decreasing irrigation time. If, under normal circumstances, one has a 60-minute irrigation time, the djemaa can shorten it to only 20 minutes so as to contemplate all the farmers. Collective interest and the constant quest for social cohesion and conflict resolution make djemaa a historically legitimized social and political institution. Oasis communities take climate hazards into account when they manage natural resources, thus showing a perfect knowledge of the environment and its constraints. We cannot really understand how oasis 
communities manage natural resources without paying close attention to the methods of production and transmission of their knowledge and expertise in all areas - technical, agronomical and legal. Long despised and considered obsolete, such knowledge and traditional skills reveal not only the foundations of the social and political structures of oasis communities, but shed light on the relationship between their society and environment.

The sustainability of oasis systems, some dating back several centuries, is a striking proof of the intrisinc bond between Society and Environment, and the need for a rational management of access to natural resources. The oasis model contains an enormous amount of information. For this reason, natural resource management must, necessarily, deal with local realities. The diversity of local communities is reflected on the diversity of their management models. Again, each model takes into account ecological, political, religious and social conditions. We should also bear in mind that the ability to cope with local constraints is mandatory for community water management. On the other hand, such management cannot be effective without the traditional institution of djemaa. Its social and political legitimacy is guaranteed by the vitality of its common law. Nevertheless, here and there we witness a process of disintegration of oasis social structures. Growing individualism is on the verge of supplanting the founding principle of oasis society, namely, the community of interests. There are various reasons for this, not simply the fragility of the environment and weather conditions. Institutional changes, such as the modernization of irrigation techniques and a new mode of economic organizationimposed by the modern State, aggravate the changes experienced by the oasis communities. These changes contribute to the profound transformation of social and political relations between the farmers.

\section{Community-based models of water management confront institutional innovations}

The community model of water management and natural resources could be maintained as long as there is political and legal ability to meet the needs of local communities and to control conflicts. We have seen that the role of the djemaa and local customary law guaranteed the rights of each farmer, but also reminded him of his duties towards the community. This cohesion must not blind us to the extreme hierarchy in social and political relations. Oasis traditional society is by no means egalitarian. The appropriation of natural resources - water being the supreme item of wealth - was structured by political, religious and fratricidal conflicts between lineages. Intensive and extensive appropriation of 
water allowed the holder to accummulate economic capital that projected him onto the political scene (Pascon, 1984a; Bédoucha, 1987; Ftaïta, 2006b). This pattern continued through Morocco's independence in 1956. The modern state could not undermine a secular lifestyle. The strength of customary and Islamic law in rural areas forced the state to negotiate reforms with local communities. Even the principle of customary water ownership could not be openly challenged, despite the fact that, since the period as a French protectorate, Morocco has a water code affirming the principle of public domain. Examples in which the state has applied this principle of public property to expropriate irrigators are rare, because the issue remains politically and socially highly sensitive and can cause conflicts with uncertain consequences. Some requirements for the use of public utilities, such as meeting the need of drinking water to urban populations, justify expropriations. The example of the irrigators in the former Tiznit oasis in southwest Morocco, expropriated in order to have their irrigation water transferred to supply drinking water to the town of Tiznit, is significant. The farmers benefitted from the treated city wastewater to irrigate their plots. However, the treatment plant broke down shortly afterward, leaving them with raw sewage for irrigation, causing environmental, health and economic impacts on the irrigators (Ftaïa, 1999).

Furthermore, national preference for modern agriculture with irrigation to reach the target of one million irrigated hectares has excluded areas where irrigation management is communal. Hence, the areas irrigated with smaller systems (in oasis zones) did not benefit from the same investments as the larger systems (ORMVA). However, both the number of hectares irrigated and the concentration of rural population in the oasis areas are far from negligible. Nonetheless, the modern state sent administrative services to this territory to keep its political and legal authority. The new government has gradually weakened the traditional djemaa, slowly preemptying its activities in local communities.

The principles guiding communities in technical and social water management have resisted state power, but the legal customary provisions for conflict resolution with regard to use and ownership of water among farmers are at odds with modern jurisdiction. Now conflicts are no longer resolved on the spot by the djemaa in accordance with local customary law, and the disputing parties are brought to court. Quarrels that only took a few days to be resolved, now can last several weeks or even months.

Gradually, the traditional djemaa are losing power and legitimacy. The latest blow was the 1992 law that created the Associations of Agricultural Water 
Users (WUAs). Although it was not specifically aimed at traditional communities of irrigators, its implementation had important implications for the future of community models for managing irrigation. In fact, the purpose of creating an associative model was to involve agricultural water users in the financial recovery of water projects and irrigation systems. These associations must include two-thirds of irrigators or be formed by state administration, such as the Regional Office of Agricultural Development (ORMVA), or the Provincial Directorate of Agriculture (DPA). The novelty of these WUAs as an institutional experiment is that they are not exclusively catered to users of large or medium irrigation works (under ORMVA control). They also include those oasis communities whose irrigators do no simply use water, but are owners with water rights.

The establishment of the Associations (WUAs) will change the management of water resources profoundly and, hence, the relationship between water users, on the one hand, and between water owners and local administrations, on the other. The situation is more complex for irrigators in areas where water management meets local criteria regarding participation in the management of adequate collective development programs. Another serious contradiction results from the fact that this new law provides for one single associative model, in stark contrast to the community model whose main characteristic is precisely its diversity of practices that interconnect the communities and are related to their specific historical and political conditions. Therefore, the single WUA model will progressively and insidiously replace the diversity of local practices. Consequently, only this WUA type of associative model would comply with the new regulations for the management of irrigation water and the financial participation of water users in agriculture. This WUA institutional innovation is certainly tempting to farmers in major irrigation schemes who strive for recognition, but would be devastating for the social cohesion of local community irrigators.

We must beware of the ideological and political dimension of any legal reform, particularly regarding the access, ownership and management of water. These reforms proposed by funding agents to change, or even privatize public water infrastructures, primarily met an economic need, for the state could not absorb the chronic deficit of large irrigated areas. It is also a disguised way for the state to withdraw without acknowledging the autonomy and ownership of water users. The experience of the WUAs in the area of Haouz in Marrakech is far from being conclusive. Bureaucracy is rampant and farmers cannot cope with administrative authorities (Mellakh, 2004 ; El Faï, 2008). The ORMVA is still present and increasingly engaged in technical development and irrigation. 
The novelty lies in the fact that it is the users themselves, trained in WUAs, who are in charge of collecting contributions. They must also participate financially in the maintenance of the irrigation network, while the state funds only a small percentage of the total. It is this principle of financial «participation» that legally justifies the WUAs. Even if water users failed to contribute financially to the development and reclaiming of irrigation schemes under ORMVA orientation for modern agriculture, collective participation would still continue to be a founding principle for community management of irrigation water. Indeed, each water owner must physically and financially participate in the maintenance of water works. Where there are traditional dams, after each flood, irrigators must participate in dam repairs and floodwater canals in preparation for the next flood. Where the water infrastructure is a khettara (qanat), each water owner must contribute financially to the cleaning of wells and underground drainage tunnels. Without their participation, the oasis system would collapse. This maintenance is part of the irrigators' duties where the infrastructure is a collective good. We have previously noted that the private share of water only makes sense as part of the collective ownership of water points. This being so, what benefits can local communities obtain by adopting the system of associative management of water, and hence the new law, and renouncing ancestral models that have amply proven their technical, social and ecological effectiveness? Can we consider this new association as a modern method to comply with the principles of "good governance" of water?

These questions call for a reconsideration of the principle of adherence to a specific form of social organization, be it community-based (traditional communities of irrigators) or association-based (association of agricultural water users), but also for the analysis of the impact of the WUAs as the new organisational model for the relations between irrigators. In the traditional model, all water owners are ex officio members of the community. It has to do with a commoninterest membership, sometimes more lively as a form of affiliation than ethnicity or linguistic identity. In the case of the water users association, membership must be accepted and approved by means of an annual fee. Moreover, the association's rules of organization and operation differ from those of the community of irrigators. By law, any association must be organized according to one model: an association committee made up of six members, plus a representative of the local administrative authority with voting rights (El Alaoui, 2004). This form of organization, and especially the presence of an administrative authority intruding in the business of irrigators may cause problems. Field experiments have revealed that farmers are suspicious of local authorities. This reaction is 
exacerbated when the authorities decide to intervene directly in their affairs. Moreover, the very creation of the WUAs is problematical. By law, the water users' association can be constituted either on the initiative of two thirds of irrigators, or by the local administration (ORMVA or DPA). There is a clear potential for the local administration to press for decisions that may supplant the community model of water management, traditionally more resistant to public authority than the associative model (apparently more receptive to local government impositions). Moreover, for a community of irrigators to have public support for the restauration of its water development project, it must organise as a WUA. Again, we can only guess the risks of financial penalties which await traditional communities that resist this form of organisation.

The second sticking point has to do with the practical arrangements for water management and the participation of irrigators if community models are replaced by WUA system. Field tests have shown how difficult it is to install the WUA model in areas of communal irrigation. The association is not easily accepted by elderly irrigators. The situation becomes more complicated when several villages get water from the same river (mountain irrigation). In this case, it is necessary to create as many WUA as there were djemaa, and a federation of the new WUAs is often required to join them together. In other communities, some WUAs put the oral customary rules in writing, which led to their redéfinition.This inscription was only possible with the support of local authorities (Bekkar et al., 2008). Occasionally, we see some local elites take over the management of water, gradually excluding the old people who had been in charge of water distribution (amghar, abbar, water guards). It is not surprising that challenging the authority of the amghar responsible for water distribution inevitably leads to conflicts of interest. In fact, the establishment of WUAs in the Haouz region is hardly a successful experience. Its tribal composition and the distance between tribal and village membership prevent cooperation external to the models recognized by the ancient djemaa (Raki \& Ruf, 2006). Elsewhere, WUAs oscillate between a real WUA and a contractual association that is only activated when there is work to be done. The example of the WUAs in rural Ain Leuh (Province of Ifrane) is significant (Bekkar et al., 2008). It mediates between irrigtors and the administration. We believe that this sort of association, we may describe as contractual, must be legally recognized in such a way as not to undermine the traditional model of irrigation management, because it stays close to local realities and thus better able to meet the irrigators' needs. 
We believe that in old community irrigation areas where there has been a shift in social structure in recent years, this type of association may revive the old djemaa practices, and thus strengthen cohesion in the communities of irrigators.

Without being unduly pessimistic, we notice that some oases undergo serious problems that threaten their sustainability. The causes for this are many. However, the social and environmental degradation and imbalance that have been observed do not involve all oases. Some imbalances are purely environmental (droughts, low flux of groundwater, salinization), while others are due to socioeconomic and institutional changes (population growth and pressure on natural resources, particularly on water resources, new agricultural ventures demanding greater water consumption, urbanization and fragmentation of irrigable land, new uses of water and state intervention without actual knowledge of oasis societies). The real problem is the issue of access to water. Faced with water scarcity in collectively owned hydraulic plants, some farmers rush to heavy investment in individual pumping. Admittedly, these pumps have improved the living conditions of some farmers, allowing them to irrigate additional land and enter the market economy. They grow more vegetable crops that are economically more profitable than the traditional cereals. However, this does not benefit those who are bitterly disappointed as they see water beds getting lower and the foretold demise of their oasis. In some oases, khettara has been abandoned due to overexploitation of upstream ground water with wells equipped with motor pumps, and the use of collective pumping for the survival of the oasis (Ftaïta, 2010a).

We have analyzed the social, economic, legal and political implications of customary law and traditional institutions. What is the real scope of these customary rights today? Needless to say, the modernization of political and legal institutions in North Africa has resulted in the delegitimation of the old djemaa system and, therefore, of community-based models of water management. As we talk about decentralization policies and «good governance,» it would be wise to consider that the organizational structures of oasis communities are better able to respond to local constraints, and help them revitalizing both their material and immaterial heritage. The knowledge and expertise of oasis communities are instructive. They have demonstrated that these ecosystems are sustainable even under the extreme environmental conditions that characterize their habitat. Environment degradation and shifts in social structure accompany the absence or loss of legitimacy of traditional institutions and their customary rights. 
Recebido em 07/08/2011

Aprovado em 20/08/2011

O antropólogo Toufik Ftaïta é docente pesquisador da Universidade de Nice Sofphia Antipolis e membro do laboratório CIRCPLES EA 3159. É especialista na questâo da água e do desenvolvimento sustentável e autor de muitos artigos e livros sobre o tema da água e sua gestão. Toufik Ftaïta é responsável pelo curso Eau, sociétés et développement durable: gestion sociale de l'eau et médiation institutionnelle no mestrado em Etnologia Transformations des sociétés contemporaines da Universidade de Nice. É ainda editor responsável da coleção Ressources Renouvelables da editora l'Harmattan. 


\section{Notes}

1. In Morocco, the experience of management association is not new. The 15 June 1924 Law establishing the ASP (Syndicated Associations Preferred) also authorized the establishment of free associations. These legal forms are the same as in France: ASA (Syndicated Associations Authorized eligible for public aid) and ASL (Free Union Associations). The latter aknowledges legal groups of irrigators by the administration. However, the ASPtype of association could not really work after Morocco's independence. The experience of some associations formed by certain Regional Offices for Agricultural Development (Haouz, Sous), after consulting local authorities, had legal limits (Pascon, 1984b).

2. There are different types of oasis hydraulic works: springs, traditional dams, khettara or foggara called qanat in the Middle East (a kind of subterranean channel that collects groundwater and directs it to surface canals that irrigate agricultural fields [Ftaita, 2010b]).

3. In the past, Rahn, or security transfer, was at the basis of real solidarity between oasis creditors and debtors. Any kind of property was subjected to Rahn (house, plot, fruit trees, water, etc.). This form of cooperation was fully consistent with the precepts of Islam's governing credit. Both creditor and debtor had their interests preserved. At the end of each Rahn period, they could reclaim their property with no interest paid. Today Rahn is no longer tolerated, only leases are allowed in the modern legal frame.

4. This provision is not a general rule. In some oases, the water owners themselves divide ther water.

5. Unlike with other holders, these five tassa cannot be sold by the water guards who can only rent them. These water parts are called chemachi in reference to the sun (chemess). They only last one day (Ftaïta, 2006a). 


\section{References}

BÉDOUCHA, G. 1987. L'eau, l'amie du puissant, el-Mâ' sâhib al-sultân. Une communauté oasienne du Sud tunisien. Paris: Édition des Archives contemporaines, coll. Ordres sociaux. BEKKARI, L ; KADIRI, Z \& N. FAISSE, N. 2008. «Appropriations du cadre de l'association des usagers des eaux agricoles par les irrigants au Maroc. Analyse comparative de cas au Moyen Atlas et Moyen Sebou ». In: M. Kuper \& A. Zairi (éds). Economies d'eau en systèmes irrigués au Maghreb. Actes du troisième atelier régional du projet Sirma, Nabeul, Tunisie, 4-7 juin 2007 / http://hal.cirad.fr/docs/00/26/20/57/PDF/16_Bekkari.pdf.

BOUDERBALA, N. 1984. «Le régime juridique des eaux à usage agricole au Maroc ». In: PASCON, Paul et al. (eds). La question hydraulique. Petite et moyenne hydraulique au Maroc. Graphitec: Rabat. pp. 45-117.

BOUDERBALA, N. 2000. «La loi nationale entre ciel et terre ». Etudes Rurales, 155-156. http://etudesrurales.revues.org/document13.html

CHICHE, J. 1984. «Description de l'hydraulique traditionnelle ». In: PASCON, Paul Pascon et al. (eds). La question hydraulique. Petite et moyenne hydraulique au Maroc. Graphitec: Rabat. pp. 119-319.

EL ALAOUI, M. 2004. «Les pratiques participatives des associations d'usagers de l'eau dans la gestion de l'irrigation au Maroc: étude de cas en petite, moyenne et grande hydraulique ». Revue H.T.E, 130:75-84.

EL FAIZ, M. 2008. «Les Innovations Sociales et Institutionnelles de L'irrigation au Maroc: Diagnostic et Résultats Du Projet ISIIMM ». http://www.medawater-rmsu.org/ meetings/SMWRE/Presentations/Les_résultats_du_projet_ISIIMM-Maroc.pdf.

FTAITA, T. 2010a. « Les Oasis entre tradition et modernité ». In: Gestion durable et équitable de l'eau douce en Méditerranée. Mémoire et traditions, avenir et solutions, Actes des Vème Rencontres Internationales Monaco et la Méditerranée, Monaco, 26-28, mars 2009, pp. 173-189.

. 2010b. «L'hydraulique arabe, innovations techniques et transmissions des savoirs et savoir-faire ». In: T. Ftaita. (ed.). Ce que l'Occident doit aux Arabes. Cultures et sociétés, $\mathrm{n}^{\circ} 14$. Editions Téraèdre.

2006a. Anthropologie de l'irrigation. Les oasis de Tiznit. Maroc: Éditions

l'Harmattan.

2006b. «Structures politiques et irrigation dans le Maroc précolonial et colonial. Le cas des oasis de la tribu arabe des Oulad Jerrar ». Socio-anthropologie, n 17-18: 227-244. 
1999. «De l'eau d'irrigation à l'eau de la ville ». In: R. Ragain \& E. Auphan. L'eau et la ville. Éditions CTHS. pp. 197-206.

GEERTZ, C. 1972. "The wet and the dry: traditional irrigation in Bali and Morocco". Human Ecology, 1 (3):23-39.

HERZENNI, A. 1984. «Problématique de droits d'eau et d'irrigation ». In: PASCON, Paul Pascon et al. (eds). La question hydraulique. Petite et moyenne hydraulique au Maroc. Graphitec: Rabat. pp. 321-397.

HERZENNI, A. 2002. «Les ORMVA, les AUEA et la gestion participative de l'irrigation ». H.T.E., 124:37-47.

HUNT ROBERT, C. 1989. "Appropriate Social Organization? Water User Associations in Bureaucratic Canal Irrigation Systems”. Human Organization, 48(1):79-90.

LABONNE, M. 1995. «Ajustement structurel au Maroc: le secteur agricole en transition? » Options Méditerranéennes, Série B, 14:297-305.

OSTROM, E. 1992. Crafting institutions for self-governing irrigation systems. San Francisco: ICP Press, Institute for Contemporary Studies.

PASCON, P. 1984a. La maison d'Iligh et l'histoire sociale du Tazerwalt. Rabat: SMER.

PASCON, P. 1984b. La question hydraulique. 1- Petite et moyenne hydraulique au Maroc. Rabat: Graphitec.

RAKI, M. \& T. RUF. 2006. «La participation des usagers de l'eau des périmètres irrigués méditerranéens. Regards croisés sur deux modèles marocain et égyptien ». In: RICHARD, A. Richard et al. (eds). Coordinations hydrauliques et justices sociales. Actes du séminaire, novembre 2004, Montpellier, France. Cirad, Montpellier France, Colloques.

ROCHÉ, P. 1965. «L'irrigation et le statut juridique des eaux au Maroc. Géographie humaine, droit et coutumes ». Revue Juridique et Politique, Indépendance et Coopération, 1: 55 120, 255-84 et 537-61.

MELLAKH, K. 2004. «État des lieux des Associations d'Usagers des Eaux Agricoles dans la Grande Hydraulique du Haouz ». Rapport provisoire projet MEDA-ISIIMM. Montpellier: Agropolis.

SONNIER, A. 1933. Le régime juridique des eaux au Maroc. Édition Sirey.

WITTFOGEL, K. 1964. Le despotisme oriental. Paris: Édition de Minuit. 


\section{Resumo}

A gestão social da irrigação emergiu de experiências locais nas quais a história social, religiosa e política das comunidades envolvidas é um fator determinante para a compreensão dos vários métodos de manejo social e técnico da água e outros recursos naturais. Por esta razão, o conhecimento e a experiência oasianas constituem uma importante herança material e imaterial que tem contribuído para a criação de vários modelos para a gestão coletiva do acesso à água, sua apropriação e distribuição. No entanto, longe de viver em um eterno presente etnográfico, as comunidades locais de oásis estão passando por muitas transformações cujas consequências já são sentidas. Este artigo descreve, a partir de uma perspectiva antropológica, os modelos oasianos de manejo de irrigação, enfatizando suas vantagens no contexto das inovações institucionais vigentes no campo da gestão participativa de áreas de irrigação, das salvaguardas da biodiversidade, alterações climáticas e governança eficiente da água.

Palavras-chave: oásis, irrigação, gestão social da água, comunidades locais, associações de usuários da água, Marrocos

\section{Abstract}

The social management of irrigation has emerged from local experiments where the social, religious, and political history of the communities involved is a determining factor for the understanding of the various methods of social and technical management of water and other natural resources. For this reason, oasis knowledge and expertise constitute an important material and immaterial heritage that has contributed to the establishment of several models for the collective management of water access, appropriation, and distribution. Nevertheless, far from living in a perpetual ethnographic present, local oasis communities are going through many transformations the consequences of which are already felt. This article describes, from an anthropological perspective, the models of oasis irrigation management, emphasizing their advantages in the context of the current institutional innovations in the field of participatory management of irrigation areas, biodiversity safeguards, climatic change, and effective water governance.

Keywords: oasis, irrigation, social management of water, local communities, water users associations, Morocco 